\title{
KARAKTERISTIK HUJAN DAN AWAN PENGHASIL CURAH HUJAN HARIAN TINGGI BERDASARKAN DATA MICRO RAIN RADAR (Studi Kasus : Wilayah Dramaga, Bogor)
}

\author{
High Daily Rainfall-Clouds and Rain Characteristics Based on \\ Micro Rain Radar Data (Case Study : Dramaga Area, Bogor)
}

\author{
Sara Aisyah Syafira ${ }^{1)^{*}}$, Muhamad Djazim Syaifullah $^{2)}$, Findy Renggono $^{3)}$ \\ ${ }^{1,2,3)}$ Balai Besar Teknologi Modifikasi Cuaca - Badan Pengkajian dan Penerapan Teknologi, Gedung Ir. \\ Mohammad Soebagio, GEOSTECH (820), Kawasan PUSPIPTEK, Serpong, Tangerang Selatan \\ ${ }^{\star}$ E-mail : sara.aisyah@bppt.go.id
}

\begin{abstract}
Intisari
Kejadian hujan di wilayah Bogor yang seringkali dikaitkan dengan kejadian banjir di wilayah Jakarta dan sekitarnya menjadi dasar pentingnya studi karakterisasi awan-awan penghasil curah hujan harian tinggi di wilayah Bogor tersebut. Suatu instrumen cuaca, yaitu micro rain radar (MRR), merupakan instrumen yang cukup potensial dalam hal ini, tetapi belum banyak dimanfaatkan di daerah tropis, khususnya Indonesia. Dalam penelitian ini, dilakukan karakterisasi hujan dan awanawan penghasil curah hujan harian tinggi di wilayah Dramaga, Bogor berdasarkan data MRR. Hasil analisis terhadap data MRR ini dengan cukup jelas memperlihatkan bahwa kejadian hujan dengan akumulasi curah hujan harian tinggi di daerah tersebut utamanya dihasilkan oleh awan-awan konvektif yang mencapai ketinggian puncak awan sekitar $4.5 \mathrm{~km}$, dengan kejadian hujan berkisar pada siang, sore, dan malam hari.
\end{abstract}

Kata Kunci : Hujan Lebat, Awan, Micro Rain Radar.

\begin{abstract}
Rain events in Bogor area that are often associated with flood occurrences in Jakarta and surrounding areas become important basic of characterization studies of clouds producing high daily rainfall in the Bogor area. A weather instrument, namely micro rain radar (MRR), is an instrument that is considerable potential in this regard, but has not been widely used in tropics, especially Indonesia. In this study, characterization of rain and clouds producing high daily rainfall in Dramaga, Bogor based on MRR data were conducted. Analysis results of the MRR data quite clearly show that occurrences of rain with high daily rainfall accumulation in the area were mainly produced by convective clouds which reached a height of cloud tops about $4.5 \mathrm{~km}$, with rain events happened generally at afternoon, evening, and night.
\end{abstract}

Keywords : Heavy Rainfall, Cloud, Micro Rain Radar.

\section{PENDAHULUAN}

Banjir DKI Jakarta merupakan bencana yang cukup sering terjadi. Banyak faktor yang menjadi penyebab terjadinya banjir tersebut. Salah satunya yang utama, tentu saja adalah adanya kejadian hujan dengan intensitas atau curah hujan tinggi. Menurut Lestari (2002), kejadian hujan tersebut, yang memengaruhi kejadian banjir DKI Jakarta, tidak hanya kejadian hujan yang terjadi di wilayah DKI Jakarta itu sendiri, tetapi juga yang terjadi di daerah Cibinong, Bogor, Puncak dan sekitarnya. Oleh karena itu, karakteristik awan-awan penghasil hujan di daerah sekitar DKI Jakarta, Bogor khususnya, menjadi hal yang penting untuk dipelajari.
Beberapa parameter yang dapat menjadi karakteristik pembeda jenis-jenis awan tertentu berikut karakteristik hujan yang dihasilkannya yaitu tinggi dasar awan, tinggi puncak awan, kandungan butir air (liquid water content, LWC), dan distribusi ukuran butir airnya (drop size distribution, DSD). Telah banyak metode yang berkembang untuk mengamati karakteristik awan. Pengukuran dengan micro rain radar (MRR) termasuk salah satunya yang praktis dan potensial.

MRR merupakan salah satu jenis radar yang dioperasikan sebagai pembuat profil secara vertikal (berdasarkan ketinggian) sehingga tidak seperti radar cuaca lain, yang menyediakan profil berupa cakupan area. Keuntungan dari mode operasi ini yaitu data sinyal balik yang diperoleh 
dapat dianalisis/diolah menjadi konsentrasi dan ukuran butir air. (Peters et al., 2002).

MRR merupakan jenis radar yang memancarkan gelombang secara kontinyu dengan frekuensi yang termodulasi (frequency modulated-continous wave radar, FM-CW radar). Oleh karena itu, jarak target, dalam hal ini ketinggian, ditentukan dari pergeseran frekuensi yang terjadi antara yang ditransmisikan dan yang ditangkap kembali, yang bernilai tetap dan tertentu untuk jarak atau ketinggian tertentu pula. Sementara itu, parameter-parameter hujan diturunkan dari tambahan pergeseran frekuensi yang terjadi, yang dikenal dengan pergeseran frekuensi Doppler.

Kelebihan dari MRR ini adalah gabungan sistem pengoperasiannya yang secara vertikal dan pemancaran gelombangnya yang kontinyu dengan frekuensi termodulasi sehingga memungkinkan penentuan distribusi ukuran butir air berdasarkan kecepatan jatuhnya oleh tarikan gravitasi bumi yang dipengaruhi oleh ukuran butir air itu sendiri. Kecepatan jatuh butir air tersebut nantinya memengaruhi besarnya pergeseran frekuensi Doppler yang terjadi.

Jika hanya dilihat dari intensitas/ kekuatan/ power sinyal balik yang diperoleh, dapat dimungkinkan 1 target berukuran besar, beberapa target berukuran kecil namun berjumlah banyak, dan beberapa target berukuran tertentu, menghasilkan nilai yang sama untuk ketiganya. Oleh karena itu, besar pergeseran frekuensi Doppler yang terjadilah pembedanya. Selain sebaran ukuran butir air (DSD) serta kecepatan jatuh (falling velocity), terdapat pula beberapa parameter lain (parameter-parameter hujan) yang dapat diturunkan atau diperoleh dari data MRR ini, yaitu Liquid Water Content (LWC) dan Rain Rate (RR).

Beberapa pemanfaatan MRR yang telah dilakukan yaitu, Yang et al. (2013) melakukan analisis menggunakan kombinasi data MRR dan radiometer gelombang mikro untuk menentukan cloud liquid water path (LWP), dijelaskan lebih lanjut oleh bahwa LWP pada radiometer gelombang mikro utamanya terlihat saat kondisi langit cerah, sedangkan pada MRR saat kondisi hujan.

Sementara itu, Saavedra et al. (2012) memisahkan butir air hujan dengan butir air awan melalui pengamatan darat menggunakan Advanced Microwave Radiometer for Rain Identification (ADMIRARI) dan MRR. Maahn et al. (2012) mengajukan suatu metode pemrosesan data MRR untuk meningkatkan sensitivitas dan memungkinkan penggunaannya untuk pengamatan presipitasi padat seperti salju. Smith \& Blaes (2015) melakukan pengujian "storm" musim dingin menggunakan peluncuran pesawat udara AMDAR dan MRR untuk memonitor perubahan jenis presipitasi dan meningkatkan akurasi prediksi 3-6 jam-an.
Dalam proses pengujian tersebut MRR juga memperlihatkan ketinggian lapisan "melting layer" dan perubahannya, yang digunakan sebagai informasi yang berguna untuk prediksi yang lebih akurat terhadap terjadinya jenis-jenis presipitasi campuran. Penelitian kali ini bertujuan mempelajari karakteristik awan-awan hujan di daerah Dramaga, Bogor berdasarkan data MRR selama periode kegiatan Intensive Observation Period (IOP) dari tanggal 18 Januari - 16 Februari 2016.

\section{METODE}

\subsection{Waktu dan Lokasi penelitian}

Penelitian dilakukan di posko kegiatan IOP dari tanggal 18 Januari - 16 Februari 2016 yang bertempat di Stasiun Klimatologi Klas I Darmaga, Bogor. Pada lokasi inilah dioperasikan seperangkat instrumen Micro Rain Radar (MRR) sebagai penghasil data utama dalam penelitian pada artikel ini dan juga penakar hujan (rain gauge) sebagai penghasil data pendukung.

\subsection{Pengoperasian Micro Rain Radar (MRR)}

Micro Rain Radar (MRR) merupakan radar Doppler yang beroperasi secara tegak lurus (vertikal) dan memanfaatkan prinsip kerja gelombang kontinyu-frekuensi termodulasi (Frequency Modulated Continuous Wave, FMCW) pada $24.1 \mathrm{GHz}$. Ketinggian pengukuran karakteristik hujan oleh MRR dapat mencapai hingga $9 \mathrm{~km}$, dengan resolusi waktu 10 detik dan resolusi ketinggian $300 \mathrm{~m}$ (Chakravarty et al., 2014). Pada penelitian kali ini, MRR dioperasikan setiap hari dan sepanjang hari tanpa jeda.

\subsection{Pengolahan data MRR}

Data MRR diolah dengan menggunakan METEK Graphics Software untuk menampilkan data yang terukur oleh MRR dalam bentuk tampilan visual berupa grafik. Parameter yang diamati yaitu rain rate $(\mathrm{RR})$, liquid water content (LWC), dan drop size distribution (DSD).

Berikut ini beberapa persamaan yang menjadi dasar perhitungan pada MRR (Peter, 2002):

1. Kecepatan jatuh rata-rata (mean fall velocity)

$$
\mathrm{v}_{d}(z)=\int_{\mathrm{v}_{\min }}^{\mathrm{v}_{\operatorname{man}}} \eta(\mathrm{v}, z) \mathrm{v} d \mathrm{v}
$$

falling velocity, v, merupakan yang berkontribusi paling besar terhadap nilai rain rate yang terukur.

\section{Distribusi ukuran butir (drop size distribution)}

$$
N(D, z) \Delta D=\frac{\eta(D, Z)}{\sigma(D)} \Delta(D)
$$




$$
\begin{aligned}
& \eta(D, Z)=\eta(\mathrm{v}, z)\left(\frac{\partial D(\mathrm{v}, z)}{\partial \mathrm{v}}\right) \\
& \eta(\mathrm{v}, z)=\frac{C_{R}}{g_{n}(z)} z^{2} \frac{1}{l(z)} p_{r}(\mathrm{v}, z)
\end{aligned}
$$

$\mathrm{z}=$ ketinggian;

$\mathrm{D}=$ diameter butir;

$\mathrm{v}=$ kecepatan (kecepatan butir air)

$\eta(\mathrm{v}, \mathrm{z})=$ spectral volume back scatter cross section

$\operatorname{pr}(\mathrm{v}, \mathrm{z})=$ spectral echo power

3. Faktor reflektivitas radar ekuivalen, $z_{\mathrm{e}}$

$$
\begin{aligned}
& Z_{e}=\eta / A \\
& A=\frac{\pi^{5}}{\lambda^{4}}\left|\frac{m^{2}-1}{m^{2}+1}\right|
\end{aligned}
$$

$m=$ indeks refraktif kompleks air

4. Faktor reflektivitas radar, $z$

Dalam kasus $D<\lambda$ (pendekatan Rayleigh)

$$
Z_{e}=Z=\int_{0}^{\infty} N(D) D^{6} d D
$$

5. Kandungan butir air (liquid water content, LWC)

$$
\mathrm{LWC}=\rho_{w} \frac{\pi}{6} \int_{D_{\min }}^{D_{\operatorname{mix}}} N(D) D^{3} d D
$$

LWC $=\frac{\text { volume total butir air } x \text { densitas air }}{\text { volume backscatter }}$

6. Rain rate

$$
R=\frac{\pi}{6} \int_{D_{\operatorname{mix}}}^{D_{\max }} N(D) v(D) D^{3} d D
$$

\subsection{Pengukuran dan Pengumpulan Data Curah Hujan}

Data curah hujan diperoleh dari pengukuran volume air yang tertampung pada penakar (rain gauge) setiap pukul 07.00 WIB dan dicatat sebagai curah hujan harian dengan satuan $\mathrm{mm}$.

\section{HASIL DAN PEMBAHASAN}

Selama periode kegiatan IOP pada penelitian ini, akumulasi curah hujan harian yang tercatat di lokasi penelitian (Darmaga, Bogor) adalah seperti pada Tabel 1 berikut. Dari 29 hari data curah hujan tersebut, dipilih hari dengan total curah hujan yang cukup tinggi, yaitu lebih dari $30 \mathrm{~mm}$ untuk diamati karakteristiknya berdasarkan data MRR.

Mengacu kepada BMKG (Badan Meteorologi Klimatologi dan Geofisika) intensitas curah hujan terbagi atas 4 kategori, yaitu:

1. Hujan ringan : $1-5 \mathrm{~mm} / \mathrm{jam}$ atau $5-20 \mathrm{~mm} / \mathrm{hari}$;

2. Hujan sedang : $5-10 \mathrm{~mm} / \mathrm{jam}$ atau $20-50$ $\mathrm{mm} /$ hari;

3. Hujan lebat : $10-20 \mathrm{~mm} / \mathrm{jam}$ atau $50-100$ $\mathrm{mm} /$ hari; dan

4. Hujan sangat lebat : $>20 \mathrm{~mm} / \mathrm{jam}$ atau $>100$ $\mathrm{mm} /$ hari

Intensitas tertinggi kejadian hujan di lokasi pengamatan selama IOP berada pada kategori sedang. Oleh karena itu, penelitian kali ini menggunakan data pada semua hari dengan itensitas hujan sedang.

Selain itu, dipilih pula 1 hari tanpa kejadian hujan sebagai pembanding. Secara keseluruhan, terdapat 6 hari hujan yang diamati karakteristiknya berdasarkan data MRR, yaitu 26 Januari 2016, 28 Januari 2016, 31 Januari 2016, 2 Februari 2016, 8 Februari 2016, dan 14

\begin{tabular}{|c|c|c|}
\hline No & Tanggal & Curah Hujan \\
\hline 1 & 18-Jan-16 & TTU \\
\hline 2 & 19-Jan-16 & 34.2 \\
\hline 3 & 20-Jan-16 & 6.9 \\
\hline 4 & 21-Jan-16 & TTU \\
\hline 5 & 22-Jan-16 & 2.6 \\
\hline 6 & 23-Jan-16 & 2.4 \\
\hline 7 & 24-Jan-16 & 16.1 \\
\hline 8 & 25-Jan-16 & 2.8 \\
\hline 9 & 26-Jan-16 & 0 \\
\hline 10 & 27-Jan-16 & TTU \\
\hline 11 & 28-Jan-16 & 48 \\
\hline 12 & 29-Jan-16 & 18 \\
\hline 13 & 30-Jan-16 & 2.6 \\
\hline 14 & 31-Jan-16 & 30.7 \\
\hline 15 & 1-Feb-16 & 2.9 \\
\hline 16 & 2-Feb-16 & 33.5 \\
\hline 17 & 3-Feb-16 & 14.6 \\
\hline 18 & 4-Feb-16 & 3.8 \\
\hline 19 & $5-F e b-16$ & 14.7 \\
\hline 20 & $6-F e b-16$ & 1.9 \\
\hline 21 & 7-Feb-16 & 1.1 \\
\hline 22 & 8-Feb-16 & 47.7 \\
\hline 23 & 9-Feb-16 & 8.1 \\
\hline 24 & 10-Feb-16 & 14.5 \\
\hline 25 & 11-Feb-16 & 2.4 \\
\hline 26 & 12-Feb-16 & 12.4 \\
\hline 27 & 13-Feb-16 & 0.7 \\
\hline 28 & 14-Feb-16 & 39 \\
\hline 29 & 15-Feb-16 & 19.1 \\
\hline
\end{tabular}
Februari 2016. Kejadian hujan tanggal 19 Januari 2016 tidak diamati karakteristiknya berdasarkan data MRR dikarenakan proeses perekaman yang tidak lengkap.

Tabel 1. Curah Hujan Harian Dramaga Selama IOP. 
Terdapat tiga parameter yang diamati berdasarkan data MRR penilitian kali ini yaitu rain rate $(\mathrm{RR})$, liquid water content (LWC), dan drop size distribution (DSD). Rain rate merupakan intensitas curah hujan dalam suatu rentang waktu yang diberikan dan dinyatakan dalam satuan $\mathrm{mm} / \mathrm{h}$ (milimeter/hour). Sementara itu, liquid water content menunjukkan kandungan butir air yang dinyatakan dalam satuan bobot per volume $\left(\mathrm{g} / \mathrm{m}^{3}\right)$, sedangkan drop size distribution memperlihatkan sebaran ukuran butir air yang dinyatakan dalam ukuran konsentrasi jumlah dengan satuan $1 / \mathrm{m}^{3} 1 / \mathrm{mm}$ untuk masing-masing ukuran butir air yang terdeteksi.

Ketiga parameter yang diperoleh dari MRR tersebut merupakan fungsi waktu dan ketinggian. Dalam penelitian ini, parameter $R R$ hanya ditampilkan untuk ketinggian $250 \mathrm{~m}$, yang dianggap ketinggian dengan nilai $R R$ yang paling mendekati dengan nilai RR yang mencapai permukaan. Karena hanya 1 ketinggian, sumbu- $x$ pada grafik adalah waktu, sedangkan sumbu-y pada grafik adalah nilai $R R$ itu sendiri. Sementara itu untuk parameter LWC, data ditampilkan untuk setiap ketinggian. Ketinggian yang diamati yaitu kelipatan $250 \mathrm{~m}$ mulai dari ketinggian $250 \mathrm{~m}$ hingga $7750 \mathrm{~m}$.

Jadi, terdapat masing-masing 31 grafik untuk satu parameter LWC dan satu rentang waktu tertentu yang dijadikan satu dalam satu tampilan sehingga secara keseluruhan, sumbu- $x$ menunjukkan waktu yang dinyatakan dalam UTC dan sumbu-y menunjukkan ketinggian yang dinyatakan dalam $\mathrm{m}$. Nilai LWC sendiri dilihat dari indikator warna pada grafik yang mewakili kisaran nilai-nilai tertentu seperti yang terdapat pada keterangan di bagian sebelah kanan bawah grafik. Pengaturan skala (scalling) yang digunakan untuk nilai parameter LWC tersebut yaitu $0-2 \mathrm{~g} / \mathrm{m}^{3}$.

Untuk parameter DSD, penampilan data atau nilai-nilainya juga menggunakan profil indikator warna. Akan tetapi, pada grafik DSD, sumbu-x tidak menunjukkan waktu. Sumbu-x pada grafik DSD menunjukkan ukuran butir air dalam satuan $\mathrm{mm}$, dengan sumbu-y menunjukkan ketinggian. Nilai yang ditunjukkan pada grafik/profil DSD tersebut merupakan nilai rata-rata untuk kisaran waktu tertentu yang ditetapkan sendiri di awal. Jadi, nilai-nilai yang terdapat pada satu profil DSD yang sama merupakan nilai rata-rata konsentrasi jumlah butir air ukuran tertentu (sumbu-x) di ketinggian tertentu (sumbu-y) pada rentang waktu yang selalu sama pula. Pengaturan skala nilai konsentrasi jumlah butir air yang digunakan dalam penelitian ini adalah $10^{-2}-10^{9} 1 / \mathrm{m}^{3} 1 / \mathrm{mm}$.

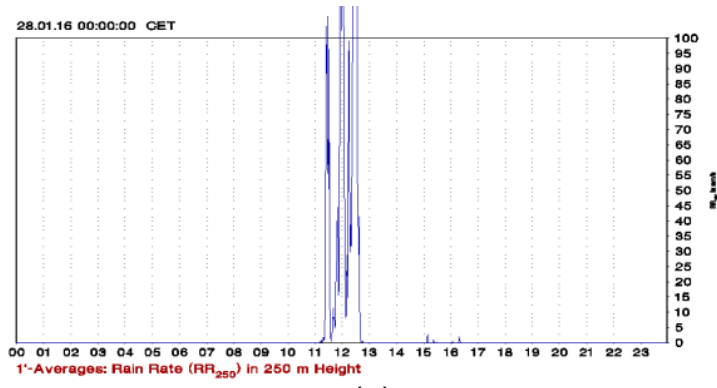

(a)

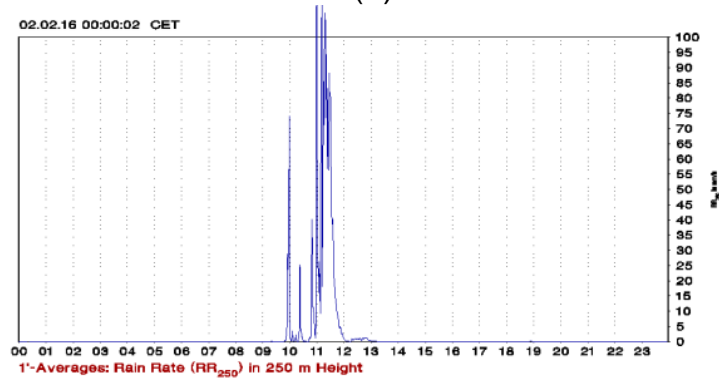

(c)

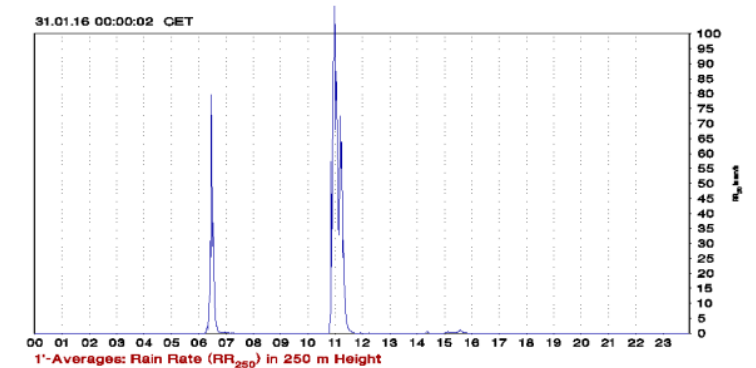

(b)

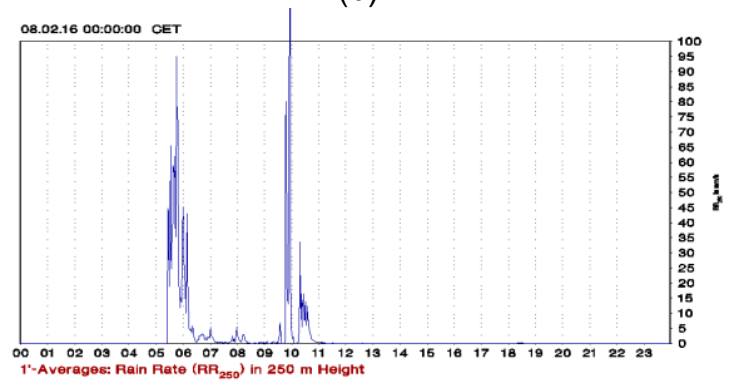

(d)

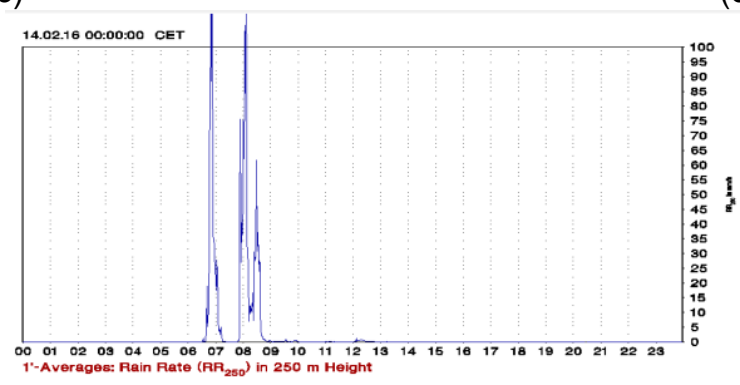

(e)

Gambar 1. Grafik rain rate pada ketinggian $250 \mathrm{~m}$ selama 1 hari pada tanggal 28 Januari (a), 31 Januari (b), 2 Februari (c), 8 Februari (d), dan 14 Februari (e) 2016. 
Gambar 1 menujukkan nilai RR pada ketinggian $250 \mathrm{~m}$ sepanjang hari pada hari-hari dengan curah hujan tinggi (lebih dari $30 \mathrm{~mm}$ ). Dari ke-5 grafik RR pada Gambar 1, terlihat bahwa pada hari-hari dengan curah hujan tinggi, kejadian hujan tidak terjadi secara merata di sepanjang hari, tetapi cenderung terpusat di kisaran waktu 5-13 UTC (12-20 WIB). Terlihat pula bahwa pada kisaran waktu tersebut pun intensitas hujan tidak merata dan cukup fluktuatif. Umumnya, terdapat dua kali periode hujan dengan kenaikan intensitas curah hujan yang drastis dan berlangsung sekitar setengah hingga 1 jam, kecuali pada tanggal 28 Januari 2016 yang mencapai sekitar 2 jam dan curah hujan penakar hari tersebut adalah yang paling tinggi yaitu $48 \mathrm{~mm}$. Dari Gambar 1 juga terlihat bahwa bahkan terdapat kejadian-kejadian hujan dengan RR yang mencapai lebih dari $100 \mathrm{~mm} / \mathrm{h}$ yang terjadi selama beberapa menit.

\subsection{Klasifikasi Kejadian Hujan}

Secara umum, terdapat dua jenis awan berdasarkan proses pembentukannya, yaitu awan-awan konvektif dan awan-awan stratiform. Dijelaskan oleh Djafri \& Haddad (2014) bahwa awan-awan konvektif adalah awan-awan yang terbentuk oleh pengangkatan masa udara yang kuat dikarenakan ketidakstabilan udara, sedangkan awan-awan stratiform adalah awanawan yang terbentuk oleh pengangkatan masa udara yang terjadi secara singkat (sinoptik) sebagai hasil dari proses dinamis pada atmosfer yang stabil, dalam suatu aliran yang bertingkat, sehingga menghasilkan sistem awan-awan dengan tekstur yang seragam, dan dapat melingkupi wilayah seluas ribuan $\mathrm{km}^{2}$. Dari kedua jenis awan ini, maka hujan yang dihasilkan pun secara umum terbagi atas 2 jenis, yaitu hujan konvektif dan hujan stratiform.

Badron et al. (2015), yang melakukan klasifikasi jenis hujan yang terdeteksi di Malaysia menggunakan radar cuaca, menyebutkan bahwa jenis hujan konvektif biasanya melibatkan suatu presipitasi yang intens dengan waktu yang relatif singkat dan ketinggian hujan yang bervariasi yang mungkin naik hingga lebih dari $13 \mathrm{~km}$. Lebih lanjut Badron et al. (2015) memaparkan bahwa hujan konvektif dicirikan dengan curah hujan yang lebat yang terjadi dalam periode yang terbatas dan biasanya mencakup wilayah yang kecil atau terlokalisir, sedangkan hujan stratiform dicirikan dengan kejadian hujan ringan atau sedang yang terjadi dalam jangka waktu yang lebih lama. Jenis hujan ini terdiri atas suatu "melting layer" yang berkembang dengan sangat baik pada suatu ketinggian konstan. "Melting layer" adalah wilayah transisi antara hujan dan salju, biasanya berawal pada suhu $0^{\circ} \mathrm{C}$ dan berakhir pada beberapa derajat di atas $0^{\circ} \mathrm{C}$, dimana keseluruhan partikel salju telah meleleh dan berubah menjadi butir-butir hujan.
Pada penelitian ini, dilakukan klasifikasi masing-masing kejadian hujan yang terdeteksi, sebagai kejadian hujan berintensitas tinggi atau kejadian hujan berintensitas rendah. Hal ini sebagai pendekatan awal terhadap kemungkinan terdeteksinya pengelompokan antara hujan-hujan konvektif dengan hujan-hujan stratiform. Pembagian kejadian hujan dilakukan berdasarkan nilai $R R$ di lapisan pengukuran paling bawah, yaitu lapisan $250 \mathrm{~m}$. Pembagian tersebut yaitu kejadian hujan dengan nilai $R R \leq$ $5 \mathrm{~mm} / \mathrm{h}$ dan kejadian hujan dengan nilai $\mathrm{RR}>5$ $\mathrm{mm} / \mathrm{h}$. Kejadian hujan dengan kategori nilai RR yang sama dan terjadi pada waktu yang saling berkesinambungan dijadikan satu kelompok kejadian hujan. Nilai $5 \mathrm{~mm} / \mathrm{h}$ ini dipilih karena waktu kejadiannya yang umumnya sangat dekat dengan kejadian kenaikan nilai RR secara drastis berdasarkan pengamatan pada grafik RR. Dengan begitu, kejadian hujan dengan nilai $R R$ > $5 \mathrm{~mm} / \mathrm{h}$ dapat merepresentasikan kejadiankejadian hujan dengan nilai RR tinggi.

\subsection{Analisis Temporal Kejadian Hujan}

Secara umum, total waktu kejadian hujan dengan nilai $R R>5 \mathrm{~mm} / \mathrm{h}$ dalam satu hari pada hari-hari dengan curah hujan tinggi berlangsung sekitar 73-89 menit dan terbagi atas 2-3 kali kejadian dengan masing-masing kejadian umumnya berlangsung sekitar 20-60 menit, walaupun terdapat juga yang berlangsung kurang dari 10 menit bahkan kurang dari 5 menit. Sementara itu, total waktu kejadian hujan dengan nilai RR lebih dari $5 \mathrm{~mm} / \mathrm{h}$ dalam sehari pada hari-hari dengan curah hujan tinggi lebih variatif, yaitu berkisar 58-260 menit dengan pembagian jumlah kejadian hujan yang juga sangat variatif.

Sifat kejadian-kejadian hujan dengan nilai $R R \leq 5 \mathrm{~mm} / \mathrm{h}$ ini juga berbeda-beda. Beberapa kejadian hujan ini kontinyu dengan kejadiankejadian hujan dengan nilai RR tinggi baik di awal (sebelum) maupun di akhir (sesudah) dengan lamanya waktu umumnya berkisar 20-30 menit walaupun ada juga yang hanya berkisar 515 menit dan ada juga yang mencapai 205 menit. Beberapa kejadian hujan yang lain terjadi secara terpisah dengan lamanya waktu tiap kejadian berkisar 40-60 menit. Terdapat juga banyak kejadian hujan berdurasi hanya sekitar 5-6 menit namun sangat berdekatan dengan kejadiankejadian hujan berdurasi 5-6 menit berikutnya dengan total waktu hujan sekitar 31 menit. Ini terjadi pada hari hujan tanggal 28 Januari 2016 pada kisaran pukul 15-16.30 UTC.

Untuk hari dengan curah hujan harian tertinggi $(48 \mathrm{~mm})$ yaitu tanggal 28 Januari 2016 , total waktu kejadian hujannya, baik kejadian hujan $>5 \mathrm{~mm} / \mathrm{h}$ maupun $\leq 5 \mathrm{~mm} / \mathrm{h}$, merupakan yang terendah, yaitu masing-masing secara berturut-turut adalah 73 menit dan 58 menit. Sementara itu, total waktu tertinggi untuk 
kejadian hujan $>5 \mathrm{~mm} / \mathrm{h}$ yaitu 89 menit dan kejadian hujan $\leq 5 \mathrm{~mm} / \mathrm{h}$ yaitu 260 menit, keduanya terjadi di hari yang sama yaitu tanggal 8 Februari 2016. Akan tetapi, nilai curah hujan harian yang terukur justru sedikit lebih rendah dibandingkan tanggal 28 Januari 2016, yaitu 47.5 $\mathrm{mm}$. Hal ini menunjukkan bahwa kejadian hujan dengan $\mathrm{RR} \leq 5 \mathrm{~mm} / \mathrm{h}$ tidak berkontribusi banyak dalam menghasilkan curah hujan harian yang tinggi meskipun terjadi selama lebih dari 4 jam. Sebaliknya, kejadian-kejadian hujan dengan nilai RR tinggilah yang paling memengaruhi terjadinya curah hujan harian tinggi. Dilihat dari waktunya, kejadian hujan $>5 \mathrm{~mm} / \mathrm{h}$ pada tanggal 8 februari memang sedikit lebih lama dibandingkan tanggal 28 Januari 2016. Namun berdasarkan nilainya, seperti yang terlihat pada grafik RR masingmasing tanggal, pada tanggal 28 Januari 2016 banyak terjadi kejadian hujan dengan nilai RR yang bahkan lebih dari $100 \mathrm{~mm} / \mathrm{h}$. Kejadian hujan inilah yang paling berkontribusi besar pada tingginya nilai curah hujan harian tanggal 28 Januari 2016.

\subsection{Perbandingan Profil LWC dan DSD}

Berdasarkan profil LWC, sebaran butir air selama kejadian hujan dengan nilai $R R$ yang tinggi di permukaan umumnya berada di lapisan paling bawah $(250 \mathrm{~m})$ hingga lapisan sekitar 3750-4750 m dengan kenaikan konsentrasi jumlah butir air yang tinggi untuk semua ukuran butir air, khususnya 3-6 mm berdasarkan profil DSD nya pada kisaran lapisan tersebut. Sementara itu, untuk kejadian hujan dengan nilai $\mathrm{RR}$ yang rendah di permukaan, sebaran butiran airnya berada di kisaran lapisan sekitar 4250$4500 \mathrm{~m}$ hingga lapisan sekitar 5000-7750 m. Namun di antara lapisan tersebut, konsentrasi butir airnya yang tinggi untuk ukuran hingga 6 $\mathrm{mm}$ hanya berkisar di lapisan sekitar $4250 \mathrm{~m}$ hingga sekitar $5000 \mathrm{~m}$. Di atas ketinggian tersebut, meskipun LWC nya tinggi, sebaran ukuran butir airnya cenderung berada di kisaran ukuran butir air yang lebih rendah (kurang dari 2 $\mathrm{mm}$ ), dengan konsentrasi jumlah butir air yang rendah untuk ukuran butir air sekitar 3 hingga 6 $\mathrm{mm}$. Selain itu, konsentrasi jumlah butir air untuk ukuran 3-6 mm tersebut juga cenderung rendah di lapisan-lapisan bawah pada kejadian hujan dengan $R R$ yang rendah.

Berikut ini, diperlihatkan lebih rinci profil LWC dan DSD untuk kejadian hujan tanggal 8 Februari 2016 yang memiliki waktu kejadian hujan terlama. Gambar 2 merupakan profil LWC tanggal 8 Februari 2016 selama 24 jam. Terlihat pada gambar tersebut bahwa sebaran LWC yang signifikan terpusat di waktu-waktu kejadian hujan. Lebih jelas terlihat pada Gambar 3 sebaran LWC pada waktu kejadian-kejadian hujan tersebut (0512 UTC).
Dengan membandingkan Gambar 3 dengan Gambar 4, yang merupakan grafik RR pada lapisan $250 \mathrm{~m}$ di rentang waktu yang sama, terlihat bahwa umumnya sebaran LWC saat kejadian hujan dengan nilai RR tinggi di lapisan bawah, tersebar mulai dari lapisan bawah hingga lapisan sekitar 3750-4250 m. Sementara itu, pada saat kejadian hujan dengan nilai $R R$ rendah di lapisan bawah, sebaran LWC cenderung berada di lapisan sekitar $4250 \mathrm{~m}$ hingga lapisan sekitar 5000-6750 m.

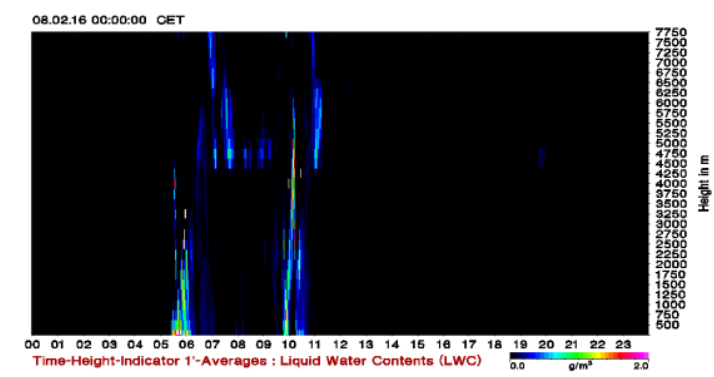

Gambar 2. Profil LWC 8 Februari 201600 - 24 UTC.

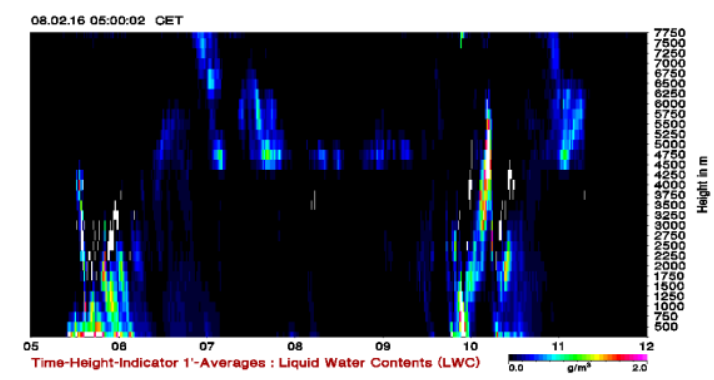

Gambar 3. Profil LWC 8 Februari 201605 - 12 UTC.

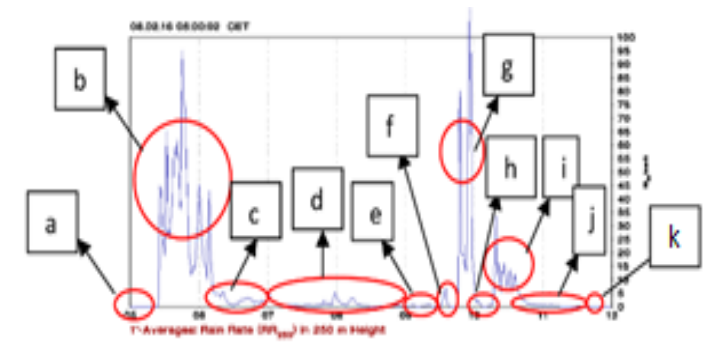

Gambar 4. Grafik RR pada lapisan $250 \mathrm{~m}$ tanggal 8 Februari 201605 - 12 UTC.

Pada saat 10 menit sebelum kejadian hujan Gambar 5(a), konsentrasi butir air berukuran $>2 \mathrm{~mm}$ sangat sedikit dari lapisan bawah hingga lapisan atas, tetapi telah terlihat lebih banyak untuk butir air berukuran 1-3 mm pada lapisan $2500 \mathrm{~m}$ hingga $4500 \mathrm{~m}$. Khususnya butir air berukuran $>2 \mathrm{~mm}$, konsentrasinya telah lebih banyak pada lapisan sekitar $3000 \mathrm{~m}$ hingga $3750 \mathrm{~m}$. Kondisi ini berbeda dengan profil ratarata distribusi ukuran butir air pada hari tidak ada kejadian hujan, tanggal 26 Januari 2016 (Gambar 6) yang mana tidak terdapat lapisan di bagian tengah yang memiliki konsentrasi butir air lebih tinggi dari lapisan di atasnya atau di bawahnya 


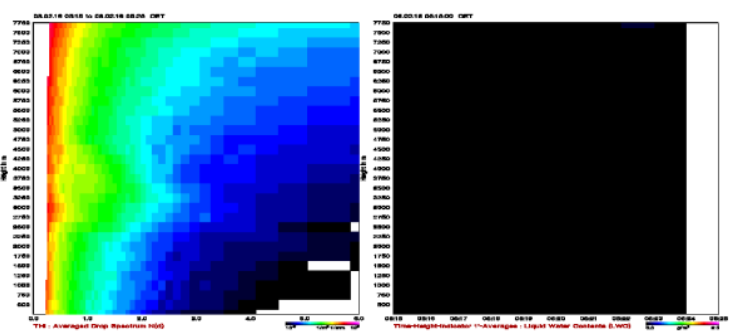

(a) 05.15 - 05.25 UTC

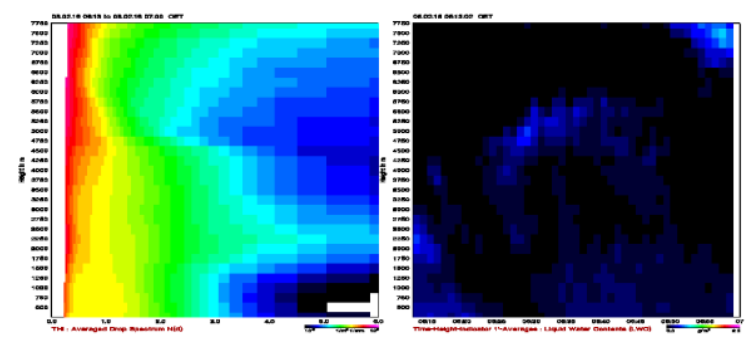

(c) $06.13-07.00$ UTC

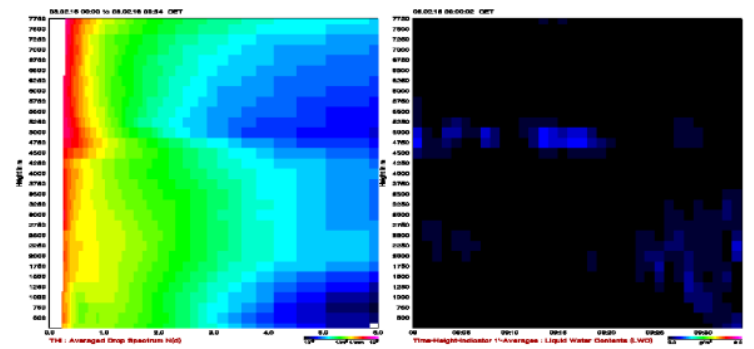

(e) $09.00-09.34$ UTC

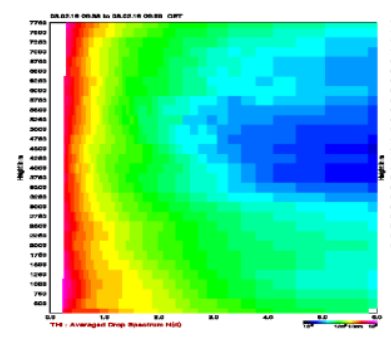

(g) 09.38 - 09.59 UTC

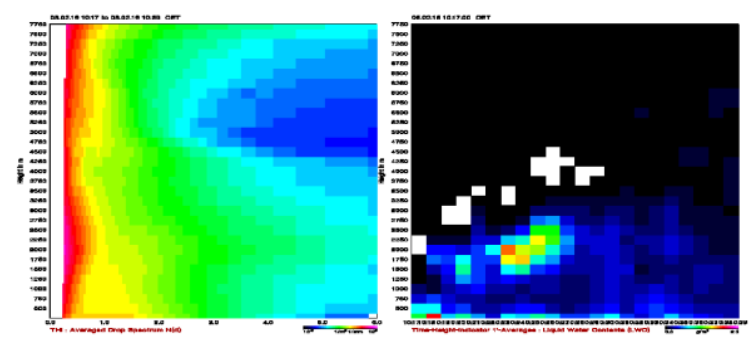

(i) $10.17-10.39$ UTC

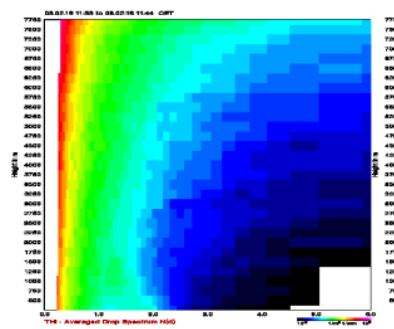

(k) $11.33-11.43$ UTC
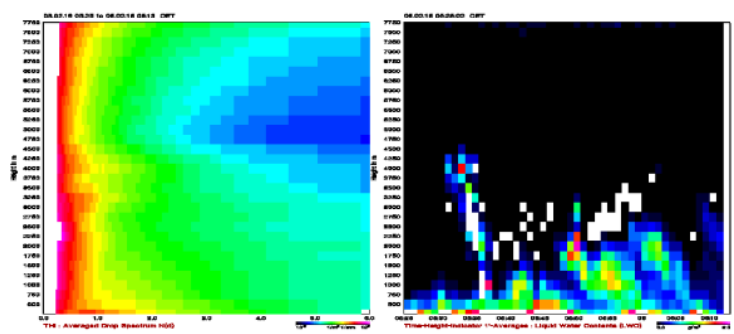

(b) $05.25-06.13$ UTC

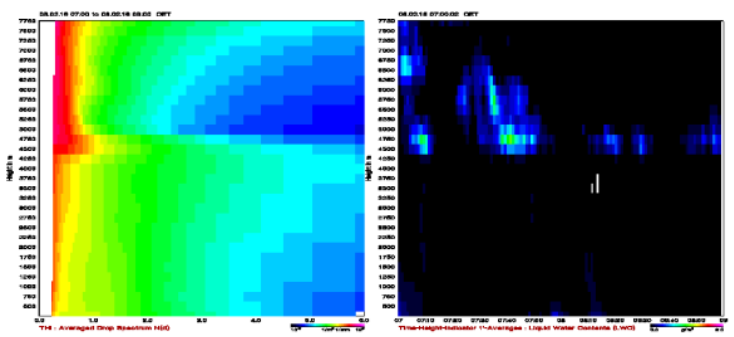

(d) $07.00-09.00$ UTC

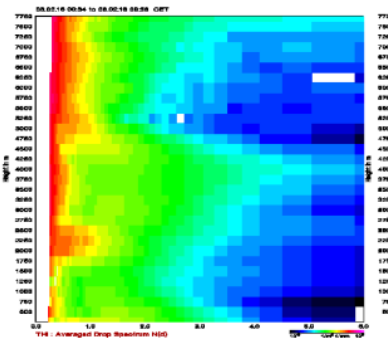

(f) $09.34-09.38$ UTC
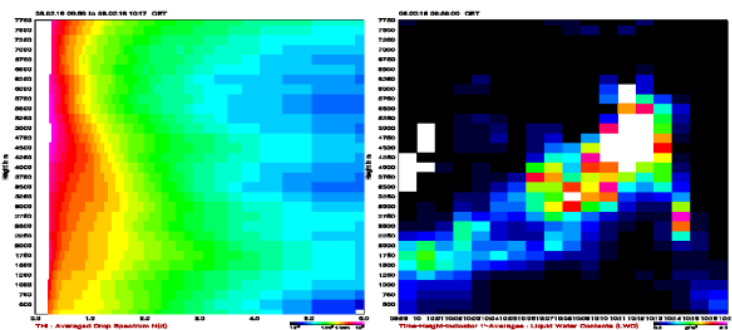

(h) $09.59-10.17$ UTC

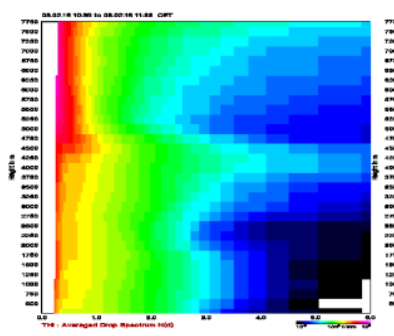

(j) $10.39-11.33$ UTC
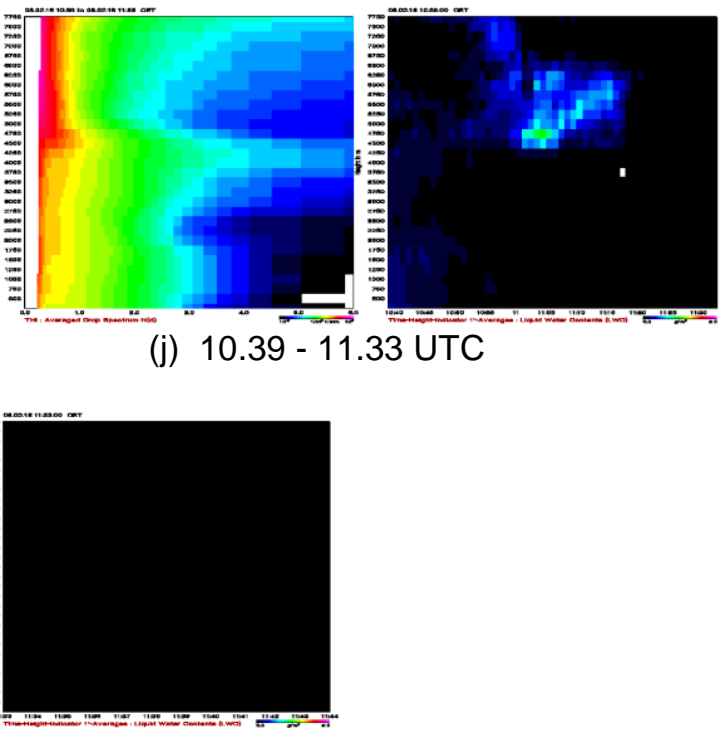

Gambar 5. (a)-(k). Profil DSD (kiri) dan LWC (kanan) kejadian hujan tanggal 8 Februari 2016. 


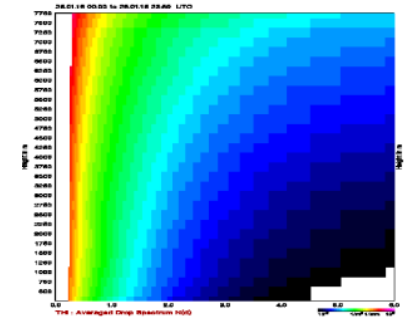

Gambar 6. Profil DSD rata-rata tanggal 26 Januari 201600 - 24 UTC.

Pada saat kejadian hujan lebat (Gambar 5 (b), (g), (i)), terjadi kenaikan konsentrasi butir air secara drastis untuk semua ukuran butir terukur (hingga $6 \mathrm{~mm}$ ) dari lapisan bawah hingga lapisan sekitar 3500-4500 m, dengan sebaran LWC yang kurang lebih juga berada pada kisaran lapisan yang sama. Sementara pada kejadian hujan dengan RR yang rendah di lapisan bawah (Gambar 5 (c), (d), (e), (f), (h), dan (j)), konsentrasi butir air yang berukuran lebih besar (3-6 mm) cenderung jauh lebih rendah, khususnya di lapisan-lapisan bawah.

Selain itu, berbeda dengan kejadian hujan lebat, pada saat kejadian hujan dengan RR rendah di lapisan bawah, sebaran LWC dengan nilai tinggi cenderung berada pada lapisanlapisan yang lebih tinggi, yaitu pada lapisan sekitar $4250 \mathrm{~m}$ hingga lapisan sekitar 5250-6500 m. Namun, dilihat dari profil DSD nya, konsentrasi butir air berukuran besar $(2-6 \mathrm{~mm})$ cenderung rendah di lapisan tersebarnya LWC tersebut.
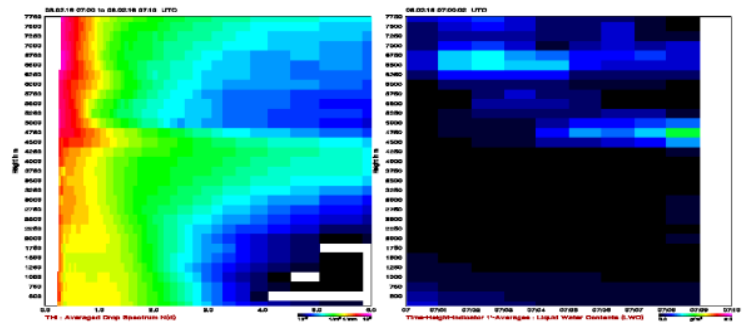

(a)
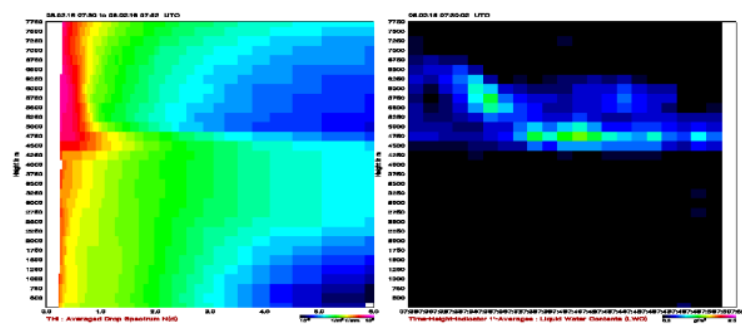

(b)

Gambar 7. Profil DSD (kiri) dan LWC (kanan) pada tanggal 8 Februari 2016 pukul $07.00-07.10$ UTC (a) dan pukul 07.30 - 07.52 UTC (b).

Lapisan dengan konsentrasi butir air tinggi untuk kurang hingga $6 \mathrm{~mm}$ berada justru di sekitar lapisan terbawah sebaran LWC (4500$4750 \mathrm{~m}$ ) hingga beberapa ribu meter di bawahnya. Namun, di bawah itu, konsentrasi butir berukuran 2-3 mm turun drastis. Pada kejadian hujan dengan RR rendah ini, distribusi ukuran butir airnya cenderung lebih terkisar pada ukuran kurang dari $3 \mathrm{~mm}$, dengan konsentasi butir berukuran 3-6 $\mathrm{mm}$ yang rendah. Hal tersebut terlihat lebih jelas pada Gambar 7(a) dan 7(b), yang memerlihatkan kondisi DSD dan LWC pada tanggal 8 Februari 2016 pukul 07.0007.10 UTC (a) dan 07.30-07.52 UTC (b).

Pada pembahasan sebelumnya, telah dinyatakan bahwa akumulasi curah hujan harian yang tinggi di wilayah Dramaga, Bogor dihasilkan utamanya oleh kejadian-kejadian hujan dengan intensitas tinggi. Dilihat dari intensitasnya yang tinggi tersebut, dan waktu berlangsungnya yang relatif singkat, hujan-hujan ini dapat dikategorikan sebagai hujan-hujan konvektif. Karakteristik hujan konvektif tersebut juga dapat dilihat dari sebaran butir airnya yang cukup luas secara vertikal, dilihat dari nilai LWC dan DSD nya yang cenderung tinggi dari lapisan bawah hingga lapisan yang cukup tinggi yaitu $3750 \mathrm{~m}-4750 \mathrm{~m}$.

\section{KESIMPULAN}

Kejadian hujan di wilayah Bogor yang menghasilkan curah hujan harian cukup besar (lebih dari $30 \mathrm{~mm}$ ) bukan berasal dari hujan yang terjadi merata sepanjang hari, melainkan hujan yang cenderung terpusat di jam-jam tertentu di siang, sore, atau malam hari. Secara umum hujan-hujan tersebut terjadi di antara sekitar pukul 5 UTC (13 WIB; siang hari) dan 13 UTC (20 WIB; malam hari). Dalam rentang waktu hujan 5-13 UTC tersebut, intensitas hujan juga tidak terjadi secara merata. Umumnya, terdapat 2 kali frekuensi hujan dengan intensitas tinggi selama sekitar setengah hingga 1 jam.

Dengan intensitas yang tinggi tersebut, dan waktu kejadiannya yang relatif singkat, serta distribusi butir-butir airnya yang secara vertikal cenderung meluas hingga mencapai lapisan yang cukup tinggi (hingga sekitar $4750 \mathrm{~m}$ atau \pm 15600 feet), khususnya untuk ukuran butir air lebih dari $2 \mathrm{~mm}$, diduga hujan-hujan tersebut berasal dari awan-awan konvektif. Jadi, secara umum, awan-awan konvektiflah yang menjadi kontributor utama curah hujan harian yang tinggi di wilayah Bogor.

\section{DAFTAR PUSTAKA}

Badron, K., Ismail, A.F., Asnawi, A.L., Nordin, M.A.W., Zahirul Alam, A.H.M., Khan, S. (2015). Classification of Precipitation Types Detected in Malaysia. Theory and Applications of Applied Electromagnetics. 344, 13-21. doi: 10.1007/978-3-319-172699_2

Chakravarty, K., Kamble, S., Das, S., Kalapureddy, M.C.R., Deshpande, S., Das, S. (2014). Characteristics of Orographic 
Precipitation by Using Doppler Radar And Disdrometer. IEEE. doi: 10.13140/2.1.4711.8727

Das, S., Shukla, A.K., Maitra, A. (2010). Investigation of Vertical Profile or Rain Microstructure at Ahmedabad in Indian Tropical Region. Advances In Space Reasearch. 45(10), 1235-1243. doi: 10.1016/j.asr.2010.01.001

Djafri, A., Haddad, B. (2014). Classification of Convective and Stratiform Cells in Meteorological Radar Images Using Svm Based on A Textural Analysis. Computer Science \& Information Technology, 4(6), 119-125. doi: 10.5121/Csit.2014.4611

Gorodetskaya, I.V., Kneifel, S., Maahn, M., Van Tricht, K., Thiery, W., Schween, J.H., Mangold, A., Crewell, S., Van Lipzig, N.P.M. (2015). Cloud and Precipitation Properties from Ground-Based RemoteSensing Instruments in East Antartica. The Cryosphere, 9(1), 285-304. doi: 10.5194/tc-9-285-2015

Kneifel, S., Maahn, M., Peters, G., Simmer, C. (2011). Observation of Snowfall with a Low-Power Fm-Cw K-Band Radar (Micro Rain Radar). Meteorology And Atmospheric Physics, 113(1), 75-87. doi: 10.1007/S00703-011-0142-Z

Konwar, M., Das, S.K., Deshpande, S.M, Chakravarty, K., Goswani, B.N. (2014). Microphysics of Clouds and Rain over the Western Ghat. Journal Of Geophysical Researches: Atmosphere, 119(10), 61406159. doi: $10.1002 / 2014 j \mathrm{j} 021606$

Leary, C.A., Houze, R.A. (1979). Melting and Evaporation of Hydrometeors in Precipitation from the Anvil Clouds of
Deep Tropical Convection. Journal Of The Atmospheric Science, 36, 669-679.

Lestari, S. (2002). Analisis Kerugian Banjir dan Biaya Penerapan Teknologi Modifikasi Cuaca dalam Mengatasi Banjir di DKI Jakarta. Jurnal Sains \& Teknologi Modifikasi Cuaca, 3(2), 155-159.

Maahn, M., Kollias, P., Kneifel, S., Gorodetskaya, I., Peter, G., Simmer, C. (2012). Measuring Snowfall with a Low-Power K-Band Radar (Micro Raind Radar) in Polar Regions. Erad 2012 - The Seventh European Conference On Radar In Meteorology And Hydrology.

Peter, G., Fischer, B., Andersson, T. (2002). Rain Observation with a Vertically Looking Micro Rain Radar (MRR). Boreal Environment Research, 7, 353-362.

Saavedra, P., Battaglia, A., Simmer, C. (2012). Partitioning of Cloud Water and Rainwater Content by Ground-Based Observations with the Advanced Microwave Radiometer for Rain Identification (ADMIRARI) in Synergy with a Micro Rain Radar. Journal of Geophysical Research, 117, 1-18. doi: 10.1029/2011jd016579

Smith, B.L., Blaes, J.L. (2015). Examination of a Winter Storm Using a Micro Rain Radar and AMDAR Aircraft Soundings. NWA Journal of Operational Meteorology, 3(14), 156-171. doi: 10.15191/Nwajom.2015.0314

Yang, H.Y., Chang, K.H., Kang, S.T. (2013). Combined Microwave Radiometer and Micro Rain Radar for Analysis of Cloud Liquid Water. Journal of The Chosun Natural Science, 6(1), 12-15. doi: 10.13160/ricns.2013.6.1.012 